\title{
IDENTIFIKASI IKM (INDUSTRI KECIL MENENGAH) KECAMATAN JEPARA KABUPATEN JEPARA
}

\author{
Agus Sarwo Edy Sudrajat ${ }^{a}$ Nella Ardiantanti Siregar ${ }^{b}$ \\ bUniversitas Semarang; Jl Soekarno Hatta Semarang; agussarwo@usm.ac.id \\ aUniversitas Semarang; JI Soekarno Hatta Semarang; nellasiregar0310@gmail.com
}

Info Artikel:

- Artikel Masuk: 12/05/21

- Artikel diterima: 31/09/21

- Tersedia Online: 31/12/21

\section{ABSTRAK}

Seiring dengan berjalannya waktu jumlah IKM yang terus meningkat dan tidak diiringi dengan pendataan inilah yang pada akhirnya menimbulkan masalah. Minimnya kesadaran untuk mendaftarkan usaha yang dimiliki masih mejadi salah satu penyebab. Padahal, hal ini penting sekali untuk dilakukan. Melihat fenomena di atas yang membuat kita menyadari akan pentingnya pendataan terhadap IKM khususnya yang ada di Kecamatan Jepara Kabupaten Jepara. Metode penelitian ini adalah menggunakan pendekatan kualitatif. Teknik analisis yang digunakan yakni analisis deskriptif dan analisis normatif. Proses validasi dan pengambilan data didasarkan pada indikator yang terdapat dalam angket. 9 indikator dalam pendataan yakni pelaku usaha IKM, Izin Usaha, Jenis Industri, KBLI, Jumlah Pekerja, Bahan Baku, Modal Kerja, Kapasitas Produksi, dan Investasi. Adapun hasil akhir dari kegiatan merupakan dokumen Induk data IKM di Kecamatan Jepara yang disusun dalam rangka mendukung kelancaran pelaksanaan pengadaan barang / jasa.

Kata Kunci : Identifikasi, Data, IKM (Industri Kecil Menengah)

\section{ABSTRACT}

Over time, The number of IKMs which continued to increase and were not accompanied by data collection was what ultimately caused problems. The lack of awareness to register a business that is owned is still one of the causes. In fact, this is very important to do. Seeing the above phenomenon makes us aware of the importance of data collection on IKM, especially those in Jepara District, Jepara Regency. This research method uses a qualitative approaches. The analysis technique used is descriptive analysis and normative analysis. The process of validation and data collection is based on the indocators contained in the querstionnaire. 9 indicators in data collection, namely IKM business actors, Business Permits, Type Of Industry, KBLI, Number Of Workers, Raw Materials, Working Capital, Production Capacity, and Investment. The final result of the activity is a data master document for IKM in Jepara District which is compiled in order to support the smooth implementation of goods / services procurement.

Keyword: Identification, Data, Small and Medium Industries (IKM)

\section{PENDAHULUAN}

Perencanaan wilayah dan kota merupakan suatu hal yang umum dan diwujudkan dengan beranekaragam cara. Salah satu caranya yakni melalui pengembangan ekonomi lokal. Konsep pengembangan ekonomi lokal bukanlah hal yang baru akan tetapi teknik implementasinya terus berkembang. Sebagai upaya untuk memperkuat daya saing ekonomi lokal yakni dengan pengembangan pada sector lokal maupun regional. Kegiatan tersebut akan berpengaruh pada pengembangan daya saing ekonomi nasional. Industri Kecil Menengah (IKM) merupakan salah satu penompang utama pemerintah dalam menciptakan lapangan kerja. Selain itu IKM merupakan bagian terpenting dari perekonomian suatu negara termasuk Indonesia. Berdasarkan Peraturan Presiden Republik Indonesia Nomor 54 Tahun 2010 tentang Pengadaan Barang / Jasa Pemerintah yang Diubah dengan Peraturan Presiden Nomor 70 Tahun 2012 dan perubahan ke empat Nomor 04 Tahun 2015, beserta Petunjuk Tehnisnya. Dalam mendukung kelancaran pelaksanaan pengadaan barang / jasa serta menghindari gangguan tehnis pada pengadaan barang / jasa pemerintah Kabupaten Jepara, maka diperlukan pembuatan Perencanaan yang baik . 
Hal ini tentu saja harus didukung dengan data yang tepat dan akurat, maka proses dalam memvalidasi data IKM yang baik dan memadahi sangat diperlukan sehingga penyusunan kebijakan untuk peningkatan Industri bisa tercapai. Menurut data yang dikemukakan oleh Kemenperin, jumlah unit IKM setiap tahunnya terus mengalami peningkatan. Pada tahun 2019 jumlah IKM tercatat sebanyak 40,99 juta unit. Kementrian Perindustrian bertekad untuk selalu memantau perkembangan industri kecil menengah. Jumlah IKM yang terus meningkat dan tidak diiringi dengan pendataan inilah yang pada akhirnya menimbulkan masalah. Minimnya kesadaran untuk mendaftarkan usaha yang dimiliki masih mejadi salah satu penyebab. Padahal, hal ini penting sekali untuk dilakukan. Pelaku IKM yang terdaftar pada sistem akan dimudahkan diantaranya mudah untuk melakukan pemasaran, memiliki pemetaaan usaha serta usahanya sudah terklasifikasi.

Melihat fenomena di atas yang membuat kita menyadari akan pentingnya pendataan terhadap IKM khususnya yang ada di Kecamatan Jepara Kabupaten Jepara. Hal ini selaras dengan bidang ilmu PWK yang multidisipliner, sehingga mahasiswa dapat memikirkan lebih jauh ilmu yang dipelajari untuk kemudian di implementasikan di dunia nyata.

\section{DATA DAN METODE}

\subsection{Pendekatan}

Pendekatan yang digunakan dalam penelitian ini adalah sebagai berikut:

\section{a. Pendekatan Kualitatif}

Pendekatan kualitatif menekankan pada makna dan pemahaman dari dalam, penalaran, definisi suatu situasi tertentu (dalam konteks tertentu), lebih banyak meneliti hal-hal yang berhubungan dengan kehidupan sehari-hari. Pendekatan kualitatif, lebih lanjut, mementingkan pada proses dibandingkan dengan hasil akhir, oleh karena itu urut-urutan kegiatan dapat berubah-ubah tergantung pada kondisi dan banyaknya gejala-gejala yang ditemukan. Pendekatan kualitatif ini juga digunakan untuk menunjang pendekatan kuantitatif untuk mengiterpretasikan hasil analisis yang berupa data numerik, untuk lebih menjelaskan suatu kondisi dalam menggambarkan kejadian yang terjadi dilapangan secara deskriptif. Tujuannya biasanya berkaitan dengan hal-hal yang bersifat praktis.

- Data yang Digunakan

Pada pendekatan kualitatif, data bersifat deskriptif, maksudnya data dapat berupa gejala-gejala yang dikategorikan ataupun dalam bentuk lainnya, seperti foto, dokumen, artefak dan catatan-catatan lapangan pada saat penelitian dilakukan.

- Teknik Pelaksanaan

Pada pendekatan kualitatif, maka yang bersangkutan akan menggunakan teknik observasi atau dengan melakukan observasi terlibat langsung mapun data sekunder /indormasi lain dari penelitian terdahulu. Dalam praktiknya, peneliti akan melakukan review terhadap berbagai dokumen, foto-foto yang ada.

\subsection{Pengumpulan Data}

Didalam kegiatan perencanaan, dalam suatu proses analisis dibutuhkan data-data yang akurat agar setiap analisis yang dilakukan diperoleh hasil yang maksimal dan sesuai dengan tujuan yang ingin dicapai. Dismaping itu diperlukan dokumentasi meliputi pengumpulan data, berupa tulisan, gambar, atau karya-karya monumental seseorang (Winarno Surakhmad, 1994)

Pengumpulan data dan analisis data merupakan kegiatan yang dilaksanakan secara bersamaan, data- data yang dikumpulkan akan langsung dianalisis sesuai dengan metode analisis yang telah dimuat diatas (Moeloeng, 1990)

Begitu pula pada penelitian ini, juga diperlukan data-data yang mendukung dan valid dari berbagai aspek yang terkait dengan tujuan yang akan dicapai. Pengumpulan data dilakukan untuk mendapatkan suatu informasi yang dibutuhkan dalam mencapai tujuan penelitian. Dalam melakukan penelitian Identifikasi Data IKM ini pengumpulan data melalui beberapa tahap.

Adapun tahapan-tahapan dalam metode pengumpulan data pada penelitian ini adalah:

i. Desain kebutuhan data 
Merupakan identifikasi data/penentuan data-data yang diperlukan dalam proses penetilian sebagai input dalam proses analisis.

ii. Teknik Pengumpulan Data

Merupakan cara yang digunakan dalam proses pengumpulan data yaitu dengan cara survei data primer dan survei data sekunder.

iii. Kompilasi Data

Merupakan pengklasifikasian data yang diperoleh untuk mempermudah interpretasi dalam proses selanjutnya.

\subsection{Pengolahan Data}

\section{a. Penyajian Data}

Adapaun hasil dari analisis akan disajikan dalam bentuk deskripsi, tabel, diagram, grafik, dan peta yang ditujukan untuk memudahkan dalam intepretasi dan pemahaman.

b. Metode Pelaksanaan Kegiatan

- Persiapan Studi

Menyiapkan perangkat/ peralatan/

perlengkapan untuk pelaksanaan

surve sekaligus koordinasi dan

manajemen pembagian tim

- Penentuan indikator

Penentian indikator yang digunakan dalam analisa spasial

- Pengolahan dan Analisa Data

Pengolahan data menggunakan software word dan excel serta GIS.

\subsection{Metode Analisis}

Dalam proses analisis akan dijelaskan analisis yang akan digunakan sesuai dengan tujuan dan sasaran yang ingin dicapai dalam peneletian ini, yaitu sebagai berikut:

Analisis kualitatif; sifat dari analisis kualitatif yang digunakan dalam penyusunan pekerjaan ini adalah untuk menganalisis data non-numerik dan menjelaskan implikasi yang timbul dari data tersebut. Analisis ini juga digunakan untuk mendukung dan menginterpretasikan hasil observasi lapangan dalam bentuk deskripsi. Analisis kualitatif merupakan metode analisis yang digunakan sebagai pendeskripsisan hasil survey primer dan sekunder pada penelitian ini. Dalam menganalisis penelitian ini digunakan pula pendekatan deskriptif dan normatif.

Metode analisis deskriptif menggambarkan kondisi atau keadaan yang berkembang di masyarakat. Pada umunya metode ini merupakan uraian atau narasi yang harus merepresentasikan keadaan yang sebenarnya tanpa dikurangi maupun ditambahi. Sedangkan Analisis normatif dilakukan terhadap keadaan yang seharusnya mengikuti suatu aturan atau pedoman. Atauran tersebut dapat merupakan standar yang ditetapkan oleh suatu instansi maupun landasan hukum lainnya.

\section{HASIL DAN PEMBAHASAN}

\subsection{Analisa Profil IKM}

Kecamatan Jepara sebagai kota perdagangan dan jasa menjadi pusat transaksi dan distribusi barang dan jasa. Dalam pembangunan sektor industri dan perdagangan diarahkan untuk menumbuhkankembangkan industri perdagangan dengan mengutamakan industri / usaha kecil menengah melalui peningkatan pengetahuan dan ketrampilan sumberdaya manusia di era perdagangan bebas produk. Pada saat struktur perekonomian daerah Kabupaten Jepara didominasi oleh sektor industri pengolahan. Oleh karena itu kegiatan ekonomi kerakyatan yang berbasis sumberdaya lokal berupa IKM.

Industri Kecil Menengah memegang peranan penting bagi perekonomian Kecamatan Jepara, karena sektor ini dapat mengatasi permasalahan pemetaan dalam distribusi pendapatan antar wilayah. Industri Kecil Menengah dapat dimaksimalkan dengan baik untuk menghadapi dunia perekonomian diluar.

\subsection{Analisa profil IKM Berdasarkan Usaha}

Berdasarkan produktivitas Industri Kecil Menengah Kecamatan Jepara terbagi kedalam tiga kategori yakni berdasarkan sektor, jenis produk dan bahan baku. Klasifikasi produktivitas beradasarkan sektor yakni pengelompokan lingkup usaha. Sesuai pada Tabel 1. Kecamatan Jepara masuk kedalam sektor usaha pengolahan makanan 
kecil, industrin konveksi, industri furniture dari kayu, industri logam dasar/ logam mulia, industri kain tenun, dan industri kerajinan rotan. Industri makanan kecil yang ada di Kecamatan Jepara memiliki 20 bidang usaha dengan jumlah perusahaan sebanyak 252. Industri konveksi yang ada berjumlah 1 . Sedangkan industri furniture merupakan industri yang mendominasi dengan 112 bidang usaha dan 519 jumlah perusahaan. Selain furniture terdapat industri logam dengan 1 bidang dan 13 perusahaan. Pada Kecamatan Jepara juga terdapat industri kain tenun dengan jumlah industri sebanyak 1 . Potensi kayu menjadikan Jepara memiliki industri lain selain furniture yakni kerajinan rotan. Industri kerajinan rotan di Kecamatan Jepara sebanyak 91 perusahaan yang bergerak pada 23 bidang berbeda-beda.

Tabel 1. Data IKM Berdasarkan Usaha

\begin{tabular}{|c|c|l|c|c|}
\hline No & KBLI & Keterangan & $\begin{array}{c}\text { Jumlah } \\
\text { Bidang } \\
\text { Usaha }\end{array}$ & $\begin{array}{c}\text { Jumlah } \\
\text { Perusahaan }\end{array}$ \\
\hline 1 & 10750 & $\begin{array}{l}\text { Industri } \\
\text { Makanan } \\
\text { Kecil }\end{array}$ & 20 & 252 \\
\hline 2 & 14111 & $\begin{array}{l}\text { Industri } \\
\text { Konveksi }\end{array}$ & 1 & 1 \\
\hline 3 & 31001 & $\begin{array}{l}\text { Industri } \\
\text { Furniture Dari } \\
\text { Kayu }\end{array}$ & 112 & 519 \\
\hline 5 & 13123 & $\begin{array}{l}\text { Industri } \\
\text { Logam Dasar/ } \\
\text { Logam Mulia }\end{array}$ & 1 & 13 \\
\hline 6 & 16291 & $\begin{array}{l}\text { Industri } \\
\text { Kerajinan } \\
\text { Rotan }\end{array}$ & 3 & 91 \\
\hline & & Jumlah & 158 & 880 \\
\hline
\end{tabular}

Sumber: Analisis, 2020 konsumen. Bahan baku industri yang ada pada data induk IKM Kecamatan Jepara terdiri dari nama/ bahan produksi, jumlah, dan nilai (Rp). Dalam hal ini nama bahan berisikan tentang bahan baku yang digunakan sebagai bahan olahan untuk diproduksi nantinya. Jumlah merupakan ukuran yang dibutuhkan tiap kali produksi dimana unit atau satuannya disesuaikan dengan jenis bahan baku. Sedangkan nilai merupakan hitungan dana yang diperlukan untuk memproduksi barang. Pada gambar 3.20. bahan baku yang digunakan dalam industri pembuatan makanan ringan yakni bahan pokok seperti tepung, gula dengan jumlah rata-rata yang dibutuhkan sebanyak $7-11 \mathrm{~kg}$ dengan nilai modal bahan sebanyak 400.000-900.000. Pada industri konveksi bahan baku utama berupa kain dengan rata-rata kebutuhan kain sebanyak 25 kodi dengan moda yang dibutuhkan rata-rata 10.000.000-15.000.000. Selain itu pada industri furniture tiap industri rata-rata membutuhkan 5-6 kubik kayu dengan harga 11.000.000-16.000.000 yang nantinya akan diolah kembali. Pada industri kain tenun bahan baku utama berupa benang tenun dengan total rata-rata kebutuhan sebanyak 100-200 benang senilai lebih dari 13.000.000. Industri terakhir yakni kerajina rotan dengan bahan baku utama yakni kayu rotan sejumlah 1-2 kodi yang bernilai 8.000.000-12.000.000.

Tabel 2. Data IKM Berdasarkan Bahan Baku Industri

\begin{tabular}{|c|c|l|c|c|c|}
\hline \multirow{2}{*}{ No } & \multirow{2}{*}{ KBLI } & \multirow{2}{*}{ Keterangan } & \multicolumn{3}{|c|}{ Bahan Baku } \\
\cline { 3 - 6 } & 10750 & $\begin{array}{l}\text { Nama } \\
\text { Industri } \\
\text { Makanan } \\
\text { Kecil }\end{array}$ & $\begin{array}{c}\text { Bahan } \\
\text { Pokok } \\
\text { (Tepung, } \\
\text { gula) }\end{array}$ & 7-11 kg & $\begin{array}{c}400.000- \\
900.000\end{array}$ \\
\hline 2 & 14111 & $\begin{array}{l}\text { Industri } \\
\text { Konveksi }\end{array}$ & Kain & 25 Kodi & $\begin{array}{c}10.000 .000 \\
15.000 .000\end{array}$ \\
\hline 3 & 31001 & $\begin{array}{l}\text { Industri } \\
\text { Furniture Dari } \\
\text { Kayu }\end{array}$ & Kayu Jati & 5-6 Kubik & $\begin{array}{l}11.000 .000 \\
16.000 .000\end{array}$ \\
\hline
\end{tabular}

\subsection{Analisa Profil IKM Berdasarkan Bahan Baku Industri}

Bahan baku merupakan barang mentah yang dibeli dan digunakan dalam membuat produk akhir barang jadi yang akan dijual ke 


\begin{tabular}{|c|c|l|c|c|c|}
\hline \multirow{2}{*}{ No } & \multirow{2}{*}{ KBLI } & \multirow{2}{*}{ Keterangan } & \multicolumn{3}{|c|}{ Bahan Baku } \\
\cline { 4 - 6 } & \multirow{2}{*}{24202} & $\begin{array}{l}\text { Industri } \\
\text { Logam } \\
\text { Dasar/ } \\
\text { Logam Mulia }\end{array}$ & Logam & Jumlah & Nilai \\
\hline 5 & 13123 & $\begin{array}{l}\text { Industri Kain } \\
\text { Tenun }\end{array}$ & $\begin{array}{c}\text { Benang } \\
\text { Tenun }\end{array}$ & $\begin{array}{c}100-200 \\
\text { Gulung } \\
\text { Benang }\end{array}$ & $\begin{array}{l}\text { 1000.000- } \\
14.000 .000 \\
15.000 .000\end{array}$ \\
\hline \multirow{2}{*}{6} & 16291 & $\begin{array}{l}\text { Industri } \\
\text { Kerajinan } \\
\text { Rotan }\end{array}$ & $\begin{array}{c}\text { Kayu } \\
\text { Rotan }\end{array}$ & $1-2$ Kodi & $\begin{array}{c}8.000 .000- \\
12.000 .000\end{array}$ \\
\hline & & Jumlah & & & \\
\hline
\end{tabular}

Sumber: Analisis, 2020

\subsection{Analisa Profil IKM Berdasarkan Jenis Produk}

Banyaknya bidang usaha yang beranekaragam dan perusahaan yang berinovasi memperoduksi suatu produk menjadikan Kecamatan Jepara memiliki jenis produk yang bervariasi. Industri makanan kecil Sebagian besar memproduksi kerupuk, tape, dan makanan ringan atau camilan. Sedangkan industri konveksi memperoduksi bahan sandang yakni pakaian. Pada industri furniture dari kayu yang mendominasi ini jenis produk yang dihasilkan rata-rata berupa meja, kursi, dipan. Industri logam dasar dan mulia memproduksi berbagai macam handcraft mulai dari gelang, kalung, dan aksesoris lainnya. Industri kain tenun yang tidak banyak ini memproduksi tenun khas Jepara yakni tenun Troso dengan berbagai corak dan model. Sedangkan pada industri terakhir yakni kerajinan rotan jenis produknya Sebagian besar berupa perkakas rumah tangga, aksesoris, hingga kerajinan.

Tabel 3. Data IKM Berdasarkan Jenis Produk

\begin{tabular}{|c|c|l|c|}
\hline No & KBLI & Keterangan & $\begin{array}{c}\text { Jenis } \\
\text { Produk }\end{array}$ \\
\hline 1 & 10750 & $\begin{array}{l}\text { Industri } \\
\text { Makanan Kecil } \\
\text { Tape, } \\
\text { Makanan } \\
\text { Ringan }\end{array}$ \\
\hline 2 & 14111 & $\begin{array}{l}\text { Industri } \\
\text { Konveksi }\end{array}$ & Pakaian \\
\hline 3 & 31001 & $\begin{array}{l}\text { Industri } \\
\text { Furniture Dari } \\
\text { Kayu }\end{array}$ & $\begin{array}{c}\text { Mebel, } \\
\text { Meja, Kursi, } \\
\text { Dipan }\end{array}$ \\
\hline
\end{tabular}

\begin{tabular}{|c|c|l|c|}
\hline No & KBLI & Keterangan & $\begin{array}{c}\text { Jenis } \\
\text { Produk }\end{array}$ \\
\hline 4 & 24202 & $\begin{array}{l}\text { Industri Logam } \\
\text { Dasar/ Logam } \\
\text { Mulia }\end{array}$ & Handcraft \\
\hline 5 & 13123 & $\begin{array}{l}\text { Industri Kain } \\
\text { Tenun }\end{array}$ & $\begin{array}{c}\text { Kain, } \\
\text { Songket, } \\
\text { Tenun } \\
\text { Troso }\end{array}$ \\
\hline 6 & 16291 & $\begin{array}{l}\text { Industri } \\
\text { Kerajinan Rotan }\end{array}$ & $\begin{array}{c}\text { Kerajinan } \\
\text { Rotan }\end{array}$ \\
\hline & & Jumlah & \\
\hline
\end{tabular}

Sumber: Analisis, 2020

\subsection{Analisa Profil IKM Berdasarkan Nilai Investasi}

Selain modal kerja, Industri Kecil Menengah Kecamatan Jepara juga didasarkan pada jumlah investasi. Investasi merupakan suatu kegiatan untuk menanamkan modal baik langsung maupun tidak. Penanaman biasanya dilakukan berupa uang maupun modal perusahaan untuk tujuan mendapat keuntungan. Sebagian besar industri yang ada di Kecamatan Jepara nilai investasinya didapatkan dari modal awal yang mereka tanam. Nilai investasi pada industri makanan kecil rata-rata berjumlah 3.500.0005.000.000 di tiap IKM. Pada industri konveksi nilai investasi terbilang besar karena besarnya skala indsutri juga mempengaruhi nilai investasi yang ditanam. Pada industri konveksi nilai investasinya sejumlah 25.000.000-30.000.000. selain itu majunya usaha furniture juga menjadikan nilai investasi pada industri furniture tergolong tinggi yakni sejumlah 28.000.000-33.000.000. pada industri logam dasar dan mulia nilai investasinya terbentang mulai dari 18.000.000.000-24.000.000 sesuai dengan besaran skala industrinya. Sedangkan pada industri kain tenun nilai investasinya sejumlah 20.000.000-30.000.000 hal ini sesuai dengan kualitas bahan produksi yang mempengaruhi harga produk. Industri terakhir yakni kerajinan rotan dimana nilai investasinya berkisar dari 17.000.000-23.000.000. 
Tabel 4. Data IKM Berdasarkan Nilai Investasi

\begin{tabular}{|c|c|c|c|}
\hline No & KBLI & Keterangan & Investasi \\
\hline 1 & 10750 & $\begin{array}{l}\text { Industri } \\
\text { Makanan } \\
\text { Kecil }\end{array}$ & $\begin{array}{c}3.500 .000- \\
5.000 .000\end{array}$ \\
\hline 2 & 14111 & $\begin{array}{l}\text { Industri } \\
\text { Konveksi }\end{array}$ & $\begin{array}{c}25.000 .000- \\
30.000 .000\end{array}$ \\
\hline 3 & 31001 & $\begin{array}{l}\text { Industri } \\
\text { Furniture } \\
\text { Dari Kayu }\end{array}$ & $\begin{array}{c}28.000 .000- \\
33.000 .000\end{array}$ \\
\hline 4 & 24202 & $\begin{array}{l}\text { Industri } \\
\text { Logam } \\
\text { Dasar/ } \\
\text { Logam Mulia }\end{array}$ & $\begin{array}{c}18.000 .000- \\
24.000 .000\end{array}$ \\
\hline 5 & 13123 & $\begin{array}{l}\text { Industri Kain } \\
\text { Tenun }\end{array}$ & $\begin{array}{c}20.000 .000- \\
30.000 .000\end{array}$ \\
\hline 6 & 16291 & $\begin{array}{l}\text { Industri } \\
\text { Kerajinan } \\
\text { Rotan }\end{array}$ & $\begin{array}{l}17.000 .000- \\
23.000 .000\end{array}$ \\
\hline & & Jumlah & \\
\hline
\end{tabular}

Sumber: Analisis, 2020

\subsection{Analisa Profil IKM Berdasarkan Ketenagakerjaan}

Banyaknya jumlah orang yang bekerja pada Industri kecil dan Menengah memperlihatkan betapa pentingnya peranan Industri Kecil dan Menengah dalam membantu memecahkan masalah pengangguran dan pemerataan distribusi pendapatan. Jika Industri Kecil dan Menengah dapat dimaksimalkan dengan baik maka Kecamatan Jepara telah siap bersaing dalam menghadapi pasar perindustrian dan perdagangan Masyarakat Ekonomi Asean nantinya. Pada Kecamatan jepara jumlah tenaga kerja disesuaikan dengan kebutuhan usaha masing-masing. Jumlah tenaga kerja rata-rata pada Industri Kecil Menengah yang ada di Kecamatan Jepara disesuaikan dengan kebutuhan industrinya. Industri makanan ringan yang tergolong industri kecil jumlah pekerjanya tidak lebih dari 400 orang seKecamatan jepara. Jumlah tenaga kerja terbanyak berada di industri furniture dengan total pekerja sebanyak 828 laki-laki dan 488 perempuan.

Tabel 5. Data IKM Berdasarkan Ketenagakerjaan

\begin{tabular}{|c|c|l|c|c|}
\hline \multirow{2}{*}{ No } & \multirow{2}{*}{ KBLI } & Keterangan & \multicolumn{2}{|c|}{$\begin{array}{c}\text { Tenaga } \\
\text { Kerja }\end{array}$} \\
\cline { 3 - 5 } & 10750 & $\begin{array}{l}\text { Industri } \\
\text { Makanan } \\
\text { Kecil }\end{array}$ & 132 & 326 \\
\hline 2 & 14111 & $\begin{array}{l}\text { Industri } \\
\text { Konveksi }\end{array}$ & 47 & 37 \\
\hline 3 & 31001 & $\begin{array}{l}\text { Industri } \\
\text { Furniture } \\
\text { Dari Kayu }\end{array}$ & 828 & 488 \\
\hline 4 & 24202 & $\begin{array}{l}\text { Industri } \\
\text { Logam } \\
\text { Dasarl } \\
\text { Logam Mulia }\end{array}$ & 34 & 13 \\
\hline 5 & 13123 & $\begin{array}{l}\text { Industri Kain } \\
\text { Tenun }\end{array}$ & 4 & 10 \\
\hline 6 & 16291 & $\begin{array}{l}\text { Industri } \\
\text { Kerajinan } \\
\text { Rotan }\end{array}$ & 112 & 100 \\
\hline & & Jumlah & 1.157 & 974 \\
\hline
\end{tabular}

Sumber: Analisis, 2020

\section{SIMPULAN}

Berdasarkan hasil Analisa, IKM Kecamatan Jepara teridentifikasi profilnya yang didasarkan pada beberapa hal. Tercatat pada Kecamatan Jepara terdapat 5 jenis sektor industri dengan total perusahaan sebanyak 880 yang menggeluti bidang usaha berbedabeda. Bahan baku rata-rata yang dibuuthkan sesuai dengan bidang usaha masing-masing dengan rentang nilai bahan baku sebesar 400.000-16.000.000. jenis produksi yang dihasilkan bervariasi mulai dari makanan, handcraft, hingga kerajinan kayu. Besaran nilai investasi yang didapat pada masingmasing perusahaan tentunya berbeda. Rentang nilai investasi perbulan berkisar mulai dari 3.000.000-33.000.000. sedangkan secara ketenagakerjaan, inudstri kecil menengah yang ada di Kecamatan Jepara berhasil menyerap tenaga kerja sebanyak 
2.131 pekerja berjenis kelamin laki-laki dan perempuan. Dengan adanya data ini maka setiap IKM yang ada di Kecamatan Jepara diharapkan mampu melakukan pengadaan barang dan jasa yang berjalan secara terbuka, adil, tidak diskriminatif, efektih, efisien, transparan, akuntabel dan dapat dipertanggungjawabkan dalam rangka mendukung kelancaran pelaksanaan pengadaan barang / jasa.

\section{REFERENSI}

Afifuddin dan Beni Ahmad. 2009. Metodologi Penelitian Kualitatif. Bandung : Pustaka Setia.

Aminin, Ratang M. 2010. Populasi dan Sampel Penelitian 4: Ukuran Sampel. Diunduh Pada Kamis 26 November 2020.

Andriani, Intan, Dra. Nina Widowati, M.Si. 2015. Pengembangan Industri Kecil dan Menengah di Kota Semarang (Studi Kasus Pada Dinas Perindustrian dan Perdagangan Kota Semarang di Bidang Perindustrian). Semarang : Departemen Admnistrasi Publik Fakultas IImu Sosial dan IImu Politik Universitas Diponegoro.

Godam. 2006. Pengertian, Definisi, Macam, Jenis dan Penggolongan Industri di Indonesia. Perekonomian Bisnis. http://organisasi . org. diakses Tanggal 16 November 2020.

Moeloeng, Azas-azas Penelitian, (Yogyakarta :Gadjah Mada University Press, 1990),

Moleong, Lexy J. 2008. Metode Penelitian Kualitatif. Bandung : PT. Remaja Rosdakarya.

Peraturan Presiden Republik Indonesia Nomor 54/ Tahun 2010/ Tentang Pengadaan Barang atau Jasa Pemerintah.

Peraturan Kementrian Perindustrian Nomor 64/ Tahun 2016/ Tentang Industri Kecil Menengah.

Peraturan Kementrian Perindustrian Nomor 64/ Pasal 3/ Ayat 1/ Tahun 2016/ Tentang Jenis IKM.

Sugiyono. 2008. Memahami Penelitian Kualitatif. Bandung : Alfabeta.
Surat Keputusan Mentereri Perindustrian Nomor 19/ M/ 1 / 1986/ Tentang Klasifikasi Industri.

Undang-Undang Republik Indoenesia Nomor 3/ Tahun 2014/ Tentang Perindustrian.

Undang-Undang Republik Indonesia Nomor 5/ Tahun 1984/ Tentang Perindustrian. 